\title{
堆積岩の弾性波伝播速度, 圧縮強さと含水比の関係*
}

\author{
井上正 康 ${ }^{1}$ 大見美智 ${ }^{2}$ \\ 守 田 順 市 $^{3}$
}

\section{1. 緒言}

岩石の強さを知るために最も多く実施されているのは 一軸圧縮強度測定である。また岩石の強さを非破壊的に 推定しようとする方法も最近多数試みられてきている。 非破壊試験法のうちでも最も普通に実施されているのは 超音波パルス法あるいは共振法でもつて弾性波の伝播速 度や動的弹性定数を測定する方法である。なかでも超音 波パルス法による測定結果を強度試験結果に併記するこ とは一般的となってきている。

室内で圧縮強度測定や弾性波伝播速度の測定を行なう ときは, 室内放置乾燥状態の岩石供試体について実施す るのが普通である。しかし，地表あるいは地下に自然に 存在する岩石はその孔隙内部に必ず水を含んでいるので 湿潤の程度による岩石の諸性質の変化を知つておく必要 がある。

このような考えに基づいていくつかの研究がなされて きている。堀部ら ${ }^{1)} 2$ 種類の夾炭層砂岩供試体につい て, 含水比の変化にともなら一軸圧縮強さおよび共振法 による動的ヤング率の変化を測定して，圧縮強さと動的 ヤング率が含水比の指数関数で表わされることを示し た。しかし，共振法による測定において伝播速度の変化 には触れていない。また，田中 ${ }^{22}$ は一軸圧縮強さが数 10 〜数 $100 \mathrm{~kg} / \mathrm{cm}^{2}$ 程度の比較的軟かい泥岩やシルト岩につ いて含水比の変化にともなら強度の変化を測定して, 強 度が含水比の指数関数で表わされ，その変化のしかたが いくつかの型に分類できるとしている。

筆者らは岩石供試体の一軸圧縮強さ，超音波パルス法 による縱波伝播速度抢よび共振法による縦振動伝播速度 が，供試体の含水比の変化によりどのように変化するむ のであるかということに関して諸種の岩石供試体につい て実験を行なってきたが，それらのらち堆積岩について 検討した結果について報告する。

\section{2. 試料および実験方法}

本実験で使用した岩石試料は，熊本県天草細粒砂岩，

*1971年 5 月 18 日受理 昭和 43 年 3 月，日本鈗業会春季大会飞おいて一部発表

1. 正会員 工博 熊本大学教授 工学部資源開発工学科

2. 正会員 熊本大学講師 工学部資源開発工学科

3. 住友金属鉣山株式会社
熊本県天草中粒砂岩，熊本県三角粗粒砂岩㧍よび福島県 荻野の緑色凝灰岩の 4 種類である。 3 種類の砂岩はいず れも第三紀のむので，三角粗粒砂岩は天草中粒砂岩と同 一地層の砂岩であるがやや風化している。このために弾 性波の減衰が大きく，共振法による測定において特に水 浸供試体では明膫な共振周波数が求められなかつた。顕 微鏡下で観察すると長石の部分が緑泥石化しているのが 認められた。これらの岩石試料の室内放置状態における 見掛密度と孔隙率の平均值を第 1 表に示す。

これらの岩石ブロックより $3.5,5.0 \mathrm{~cm} \phi$ の円柱供試体 を簡易ボーリングマシンで抜きとり整形し，供試体の両 端面を200萧カーボランダムで研磨仕上げした。供試体の 長さは共振法測定器の測定周波数の制限により直径の約 3 倍にとつた。

超音波パルス法の測定器はシンクロスコープにパルス 発生器と増幅器を組込んだもので, 振動子には固有振動 数 $100 \mathrm{kHz}$ のチタン酸バリウム磁器のものを使用した。 共振周波数の測定器は市販のコンクリート用のもので周 波数範囲は 500 〜 $16,000 \mathrm{~Hz}$ である。

用意した供試体のすべてを約 2 週間室内放置乾燥し， その後いろいろな含水比をもつように養生した。養生状 態としては，105 110Cで炉乾燥した後シリカゲル入り のデシケータ内で室温まで泠却した状態と約 1 力月間水 中に放置して飽和含水させた状態およびそれらの中間の 養生雾囲気を得るために，一部堀部ら ${ }^{1)}$ の行なつた方法 を利用して含水状態を変化させた。それらはシリカゲル 入りデシケータ内で約 1 カ月間乾燥した状態, $\mathrm{CaCl}_{2}$ aq. sat. 状態，室内放置状態， $\mathrm{NH}_{4} \mathrm{Cl}$ aq. sat. 状態抢よ びデシケータの目血下に水を入れた状態で，これら 7 状 態のらちから適当に 6 状態を選んで養生を行なつた。 1 つの養生状態につき $4 \sim 8$ 個の供試体を用意した。

第1 表 各岩石試料の見掛密度と孔隙率

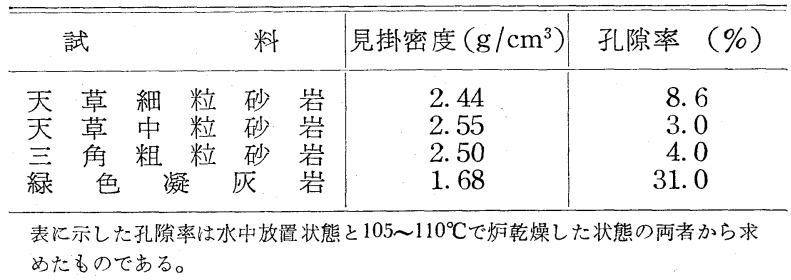




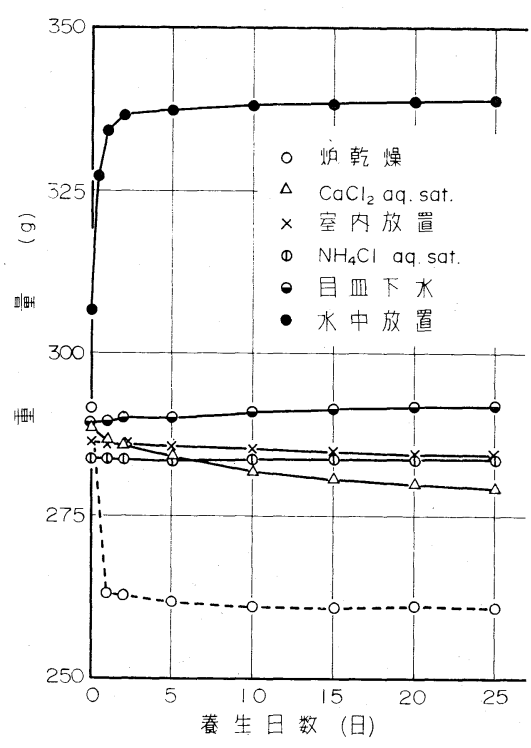

第 1 図

養生日数による重

量変化

（緑色凝灰岩）
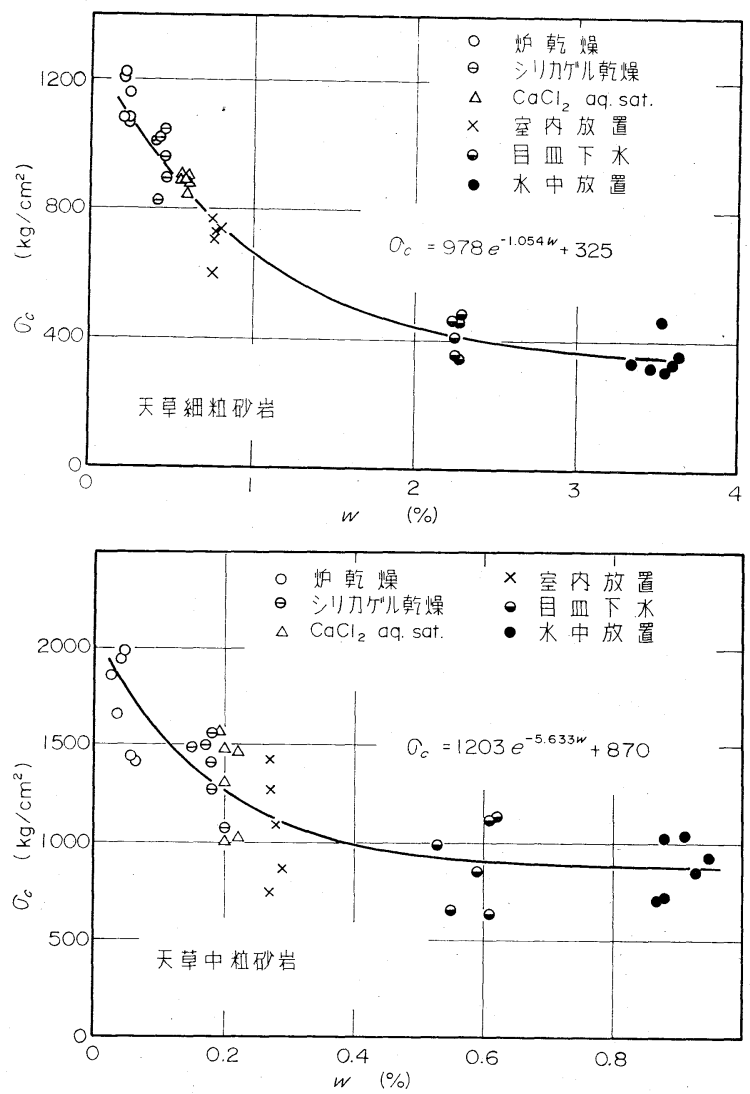

（上）第 2 図（下）第 3 図

含水比の変化にともなら一軸圧縮強さの変化

各養生方法で養生を開始してから，各状態の代表供試 体について養生の進行にともなつて生ずる重量および伝 播速度の変化を一定時間ごとに測定した。養生が進行し て各代表供試体の重量変化がほとんどなくなつたと見な せるところで（養生開始後約 1 力月間)，全供試体の見 掛密度，超音波パルス法と共振法による弾性波伝播速度 を測定し最後にアムスラー型圧縮試験機で破壊して一軸
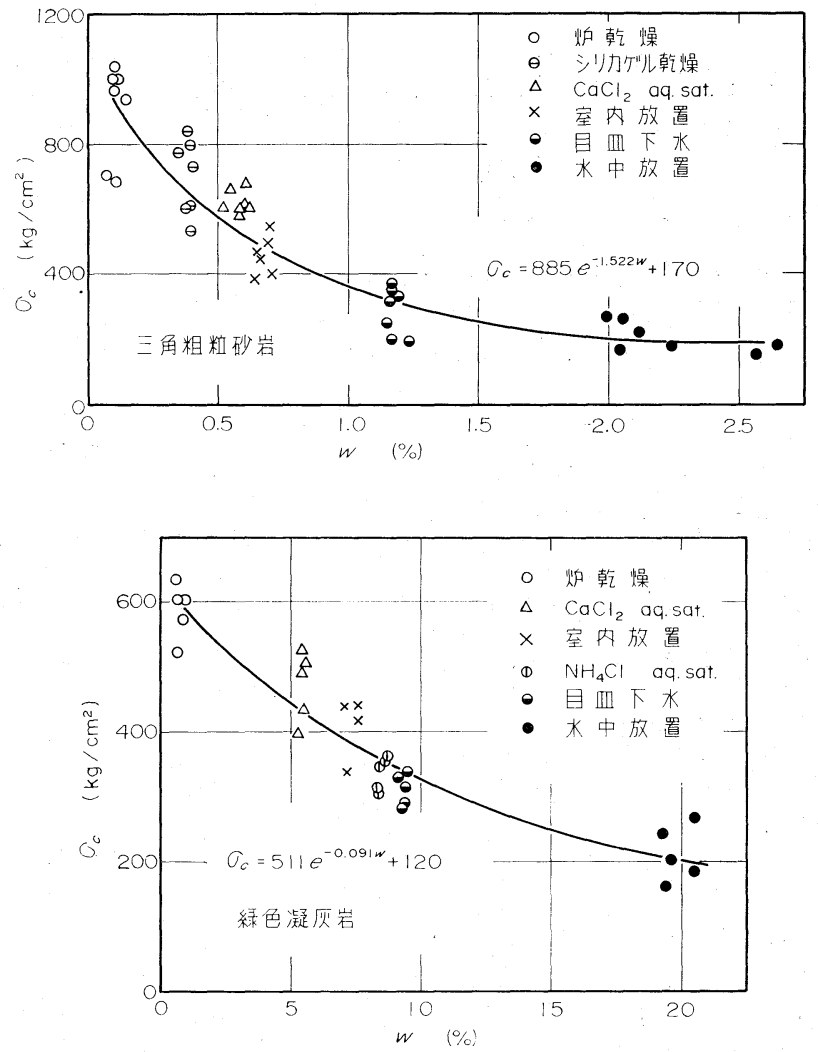

（上）第 4 図（下）第5図

含水比の変化にともなう一軸圧縮強さの変化

圧縮強さを求めた。破壊した供試体の中央部より岩片を とり $5 \mathrm{~mm}$ 以下になるように細かく砕いて, 土質試験に おける JIS A 1203 土の含水量試験方法にしたがつて 含水比を測定した。第 1 図に緑色凝灰岩の養生の進行に とすなら重量変化の例を示す。

\section{3. 実験結果および考察}

\section{$3 \cdot 1$ 含水比の変化にともなう一軸圧縮強さの変化}

岩石を乾燥させるとその強度が増加するあるいは吸水 させるとそれが低下するということは一般に認められて いることである。本実験においても，天草細粒砂岩では 炉乾燥状態での一軸圧縮強さの平均值は $1,113 \mathrm{~kg} / \mathrm{cm}^{2}$ で あるのに対し水中放置状態のそれは $349 \mathrm{~kg} / \mathrm{cm}^{2}$ であり水 浸することにより $1 / 3.2$ に低下している。同様に天草中 粒砂岩では $1 / 2.0$ に，やや風化している三角粗粒砂岩で は $1 / 4.5$ に，緑色凝兏岩では $1 / 2.8$ に低下している。本 実験で得られた含水比の変化にともなう一軸圧縮強さの 変化の結果を第 $2,3,4$ および 5 図に示す。図からわかる ように圧縮強さ $\sigma_{c}$ と含水比 $\omega の$ 間には相関関係が認めら れる。堀部ら ${ }^{1)}$ は夾炭層砂岩について両者の間に (1)式 の関係が存在することを示した。

$$
\sigma_{c}=A \cdot \mathrm{e}^{-\alpha w}+B \cdot \mathrm{e}^{-\beta w}
$$

ここで， $A, B, \alpha$ および $\beta$ は試料による定数である。筆 者らは本実験の結果より（2)式の指数関数の関係が成立 
することを認めた。

$$
\sigma_{c}=a \mathrm{e}^{-b w}+c
$$

ここで， $a, b$ および $c$ は試料による定数である。各試 料について最小 2 乗法により(2)式の各定数を求めて実 験式を決定してみた。

天草細粒砂岩について

$$
\sigma_{c}=978 \mathrm{e}^{-1.054 w}+325
$$

天草中粒砂岩について

$$
\sigma_{c}=1203 \mathrm{e}^{-5.633 w}+870
$$

三角粗粒砂岩について

$$
\sigma_{c}=885 \mathrm{e}^{-1.522 w}+170
$$

緑色凝灰岩について

$$
\sigma_{c}=511 \mathrm{e}^{-0.091 w}+120
$$

という結果を得た。

含水による岩石強度変化の機構についてまだ明確な説 明はなされていないが，比較的軟かい岩石については 2,3 の研究がある ${ }^{233}$ 。田中 ${ }^{2)}$ はシルト岩・泥岩・頁岩試 料について, 含水比を変えて圧縮試験と引張試験を行な つて破壊包絡線を求めた結果から，内部摩擦角は含水比 を変化させてもほとんど一定とみなせることより，強度 の含水比による変化は土の粘着力に相当する岩石構成粒 子相互の凝集力によつて大きく左右されるであろうとい ら考えを示している。

第 6 図に各試料のそれぞれの養生状態における含水比 と一軸圧縮強さの平均值より描いた含水比一強度線図を 示す。図に示すように半対数紙で表わすと砂岩ではある 含水比を境として折線となり，緑色凝灰岩では段違いに なつた 2 本の直線で表わされる型になつている。このよ らに含水比一強度線図上で変曲点があることからみて, このある含水比を境として含水比の大きい側と小さい側 とでは強度等に関係する孔隙水の作用が異なるものと考 えられる。含水比の大きい側では粒子間隙をみたした自 由水のため組成粒子相互がすべりやすく，とくに膠結物 質の種類によつては吸水膨潤のためルーズな状態になり 見掛の粘着力を低下させるような効果を及ぼしていると 思われる。これに対して前述のある含水比より小さい含
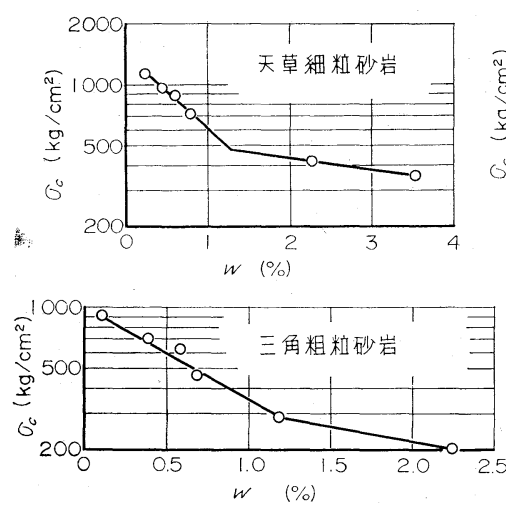

第 6 図

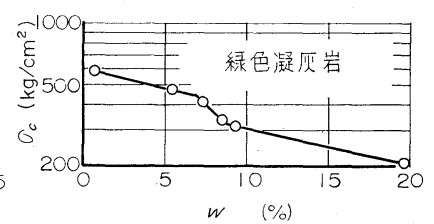

各試料にお打る含水比一強度線図

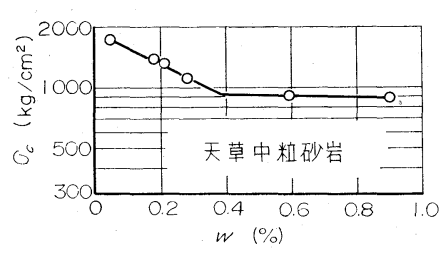

水比側では，乾燥することにより自由水が失なわれ，毛 管水あるいは吸着水といわれるものが残り，後述するよ らに毛管圧力が上昇し粒子間吸引力が増すことが強度の 増大の主因となるのであろらと考えられる。

\section{$3 \cdot 2$ 含水比の変化にともなう縱波伝播速度の変化}

超音波パルス法による弾性波伝播速度の測定は岩石の 非破壊試験の代表的なものの 1 つである。それゆえ含水 比を変化させると縦波伝播速度がどのように変化するか ということを知ることは含水比一強度の関係と同様に重 要なことであろう。

第 7,8,9 および10図に超音波パルス法によつて得られ た含水比 $w$ の変化にともなら縦波伝播速度 $V_{P l}$ の変化を 示す。図からわかるようにパルス法で $V_{P l}$ を測定すると これら 4 種類の岩石に共通してある含水比で縦波伝播速 度が最低になり，それより含水比が増加しても減少して も伝播速度は大になる。この含水比が増加して飽和状態 に近くなると縦波伝播速度が大になることはすでに南 雲 ${ }^{4)}$ や林田 ${ }^{5)}$ も報告しているし，筆者らも簡単な実験を 行なつて同様の結果を得たことを報告した ${ }^{6)}$ 。いまこの 含水比の変化にともなら縦波伝播速度の変化の原因につ いて少し考察してみる。第 $7,8,9$ および10図にそれぞれ 示した含水比一速度曲線は大きくわけて次の 3 つの領域 に分類できる。それは(I)伝播速度が最低になる含水比 より大きい含水比の部分，（II）この含水比より小さい部 分および(III)炉乾燥あるいはシリカゲル乾燥状態に相当 する非常に含水比の小さい部分である。

（I）の領域では含水比が大きくなり飽和含水状態に近 うくにつれて縦波伝播速度は増加している。パルス法に よる縦波伝播速度 $V_{P l}$ は(7)式で表わされる。

$$
V_{P l}=\sqrt{\frac{K+(4 / 3) \mu}{\rho}}
$$

ここで，Kは体積弾性率， $\mu$ は剛性率， $\rho$ は密度であ る。(7)式において, この（I）の領域内では密度の変化 は小さく, 岡性率が変化しないとすると, 縦波伝播速度 に最も影響するのは体積弾性率のみである。含水比が大 きくなつて飽和含水状態あるいはそれに近い状態になる と孔隙内に水がないときの岩石骨組の体積弾性率 に，水の体積弾性率がある割合で加わつて岩石全 体の体積弾性率は大きくなる。それゆえ（I）の領 域で含水比が増加して飽和含水状態に近づくと縦 波伝播速度が大になる。もちろん，このときに孔 隙率の大小により縦波伝播速度の増加の程度が異 なるし，また岩石を構成する物質の圧縮率を $C_{s}$, 孔 隙の圧縮率を $C_{p}$ とすると, その比 $C_{p} / C_{s}$ の違いに よつても増加の程度が異なる。この縦波伝播速度 が飽和含水することによつてどの程度増加するか といらことに関しては筆者らも以前に詳しく検討 しだ? 
（II）の領域では，含水比が小さくなるにしたがい縱波 伝播速度が増加する。この領域化拈ける伝播速度の変化 の原因は，前の一軸圧縮強さの項で簡単に述べたのと同 じく乾燥による孔隙内部の毛管圧力の増大に起因すると 考兄られ，岩石内部の孔隙中に発生した毛管圧力があた かも岩石の外周より加えられる圧力と同様な作用を演 じ，このため加圧下に置かれた岩石の弾性波伝播速度の
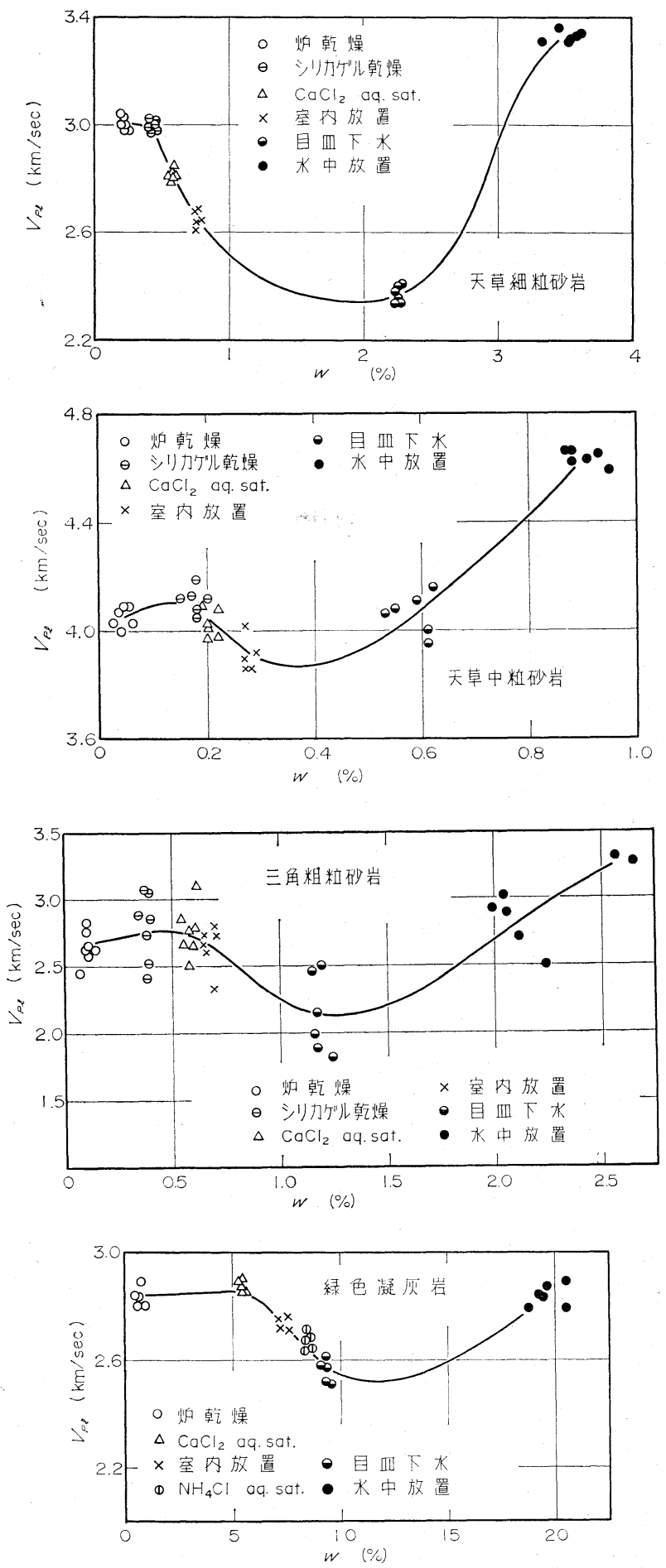

上より 第 $7,8,9,10$ 図 含水比の変化にともなら縦波伝播速度の変化
増加と同様な効果を生ずるものと思われる。

いま，毛管圧力の変化について少し検討してみる。毛 管水は水の表面張力によって孔隙に保有されている水で あるが，第11図に示すような相接しているモデル球の間 にできる水楔を考光てみる ${ }^{8)}$ 。弧状水面の内側作用す る圧力は外側化作用する圧力ょりも小さい。その圧力差 ないし負圧が毛管圧力またはサクションと呼ばれている もので，これを $p ，$ 表面張力を $T$ ，表面の曲率半径をそ れぞれ $R_{1}, R_{2}$ とすると

$$
p=T\left(\frac{1}{R_{1}}-\frac{1}{R_{2}}\right)
$$

球の半径を $d / 2$ とすれば

$$
\left.\begin{array}{l}
R_{1}=\frac{d}{2}(\sec \theta-1) \\
R_{2}=\frac{d}{2}(1+\tan \theta-\sec \theta)
\end{array}\right\}
$$

であるので (8)式は

$$
p=\frac{2 T}{d} \cdot \frac{2+\tan \theta-2 \sec \theta}{(1+\tan \theta-\sec \theta)(\sec \theta-1)}
$$

となり，負圧の大きさ $p$ はの関数であることがわか る。いま水温 $20^{\circ} \mathrm{C}$ のきの表面張力を $T=0.07357 \mathrm{~g} / \mathrm{cm}$ として， $\theta$ を種々変化させて $p$ の值を計算した結果を第 12 図に示す。図に示すように等しい $\theta$ 亿対しては $d$ が小

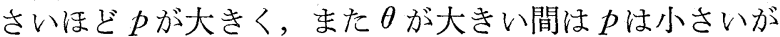
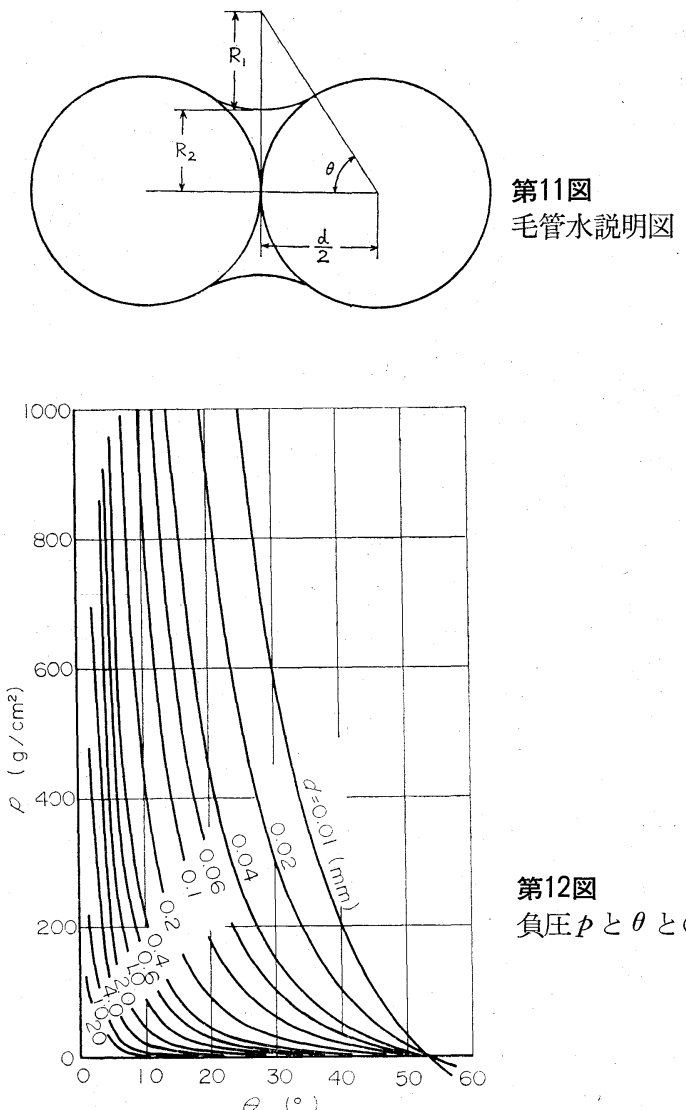

第12図

負圧 $p$ と $\theta$ との関係 
孔隙中の水分が減少して $\theta$ が小さくなるにしたがつて $p$ が大きくなることがわかる。

つぎに(III)の領域は含水比の非常に小さい領域である が，含水比が変化しても縦波伝播速度はほとんど変化し ない。この領域においては伝播速度は変化しないが圧縮 強さは含水比の減少とともに増加するといら結果が得ら れた。本実験とは別に筆者らは，この領域を含む $150^{\circ} \mathrm{C}$ までの温度等の乾燥条件を変えて, 安山岩と砂岩につい てより詳細な実験的検討を行なつてやはり同様の結果を 得たが，伝播速度と圧縮強さの乾燥に対する傾向の違い の原因を解明するまでに至つていない ${ }^{9)}$ 。ここで考慮し ている孔隙中の水は自由水あるいは吸着水と称されてい るものであるが，これらは $110^{\circ} \mathrm{C}$ の炉乾燥で脱水すると されているので ${ }^{10)}$ ，さらに高温の領域では別の機構を考 える必要があろう。

\section{$3 \cdot 3$ 含水比の変化にともなう縦振動伝播速度の変化}

第13，14および15図に共振法により得られた含水比 の変化にともなら縦振動伝播速度 $V_{R l}$ の変化を示す。図 からわかるように共振法で $V_{R l}$ を測定すると, 含水比の 変化にともなう $V_{R l}$ の変化はパルス法における (II), (III)の領域に抢ける $V_{P l}$ の変化の傾向と似ている。しか し，パルス法において含水比が増加すると伝播速度 $V_{P l}$ が大になつた（I）の領域に相当するところで縦振動伝播 速度 $V_{R l}$ が増加せず, 含水比が増加して飽和含水状態に 近づいても $V_{R l}$ はほとんで変化しないかあるいはやや減 少する傾向を示していることが，パルス法の測定結果と 大いに異なる。

(II)の領域で縦振動伝播速度 $V_{R l}$ が変化するのはパル ス法による $V_{P l}$ の変化と同様に主として孔隙内に存在す る毛管圧力の効果によるものと考えられる。

( I )の領域において共振法で $V_{R l}$ を測定すると含水比 の増加とともに $V_{R l}$ が減少することに関しては, G. H. F. Gardner ${ }^{11)}$ が難解な理論を示しているが，近似的に は半径方向の慣性効果を考慮した bar velocityに関する Rayleighの振動方程式の考えでも説明される。つまり, 供試体が吸水すると密度が増加するので共振に必要な運 動エネルギーが大になり, その結果振動数は密度の平方 根に反比例して減少する。しかし, 含水比が増加するこ とによる密度の増加はわずかであるから, 飽和含水状態 に近づいても共振周波数の低下は小さい。

ところで，パルス法や共振法による伝播速度の変化の 原因に関して上記のような説明を与えると，パルス法に よる測定結果において（I ）と（II）の領域の境界で伝播速 速度が最低になるところあるいは共振法による測定結果 において含水比の増加とともに縦振動伝播速度が急激な 低下から水平に近くなるところは，一軸圧縮強さにおい て筁管圧力の効果が現われはじめるところつまり第 6 図 に半対数で示した含水比一強度線図の変曲点に相当する
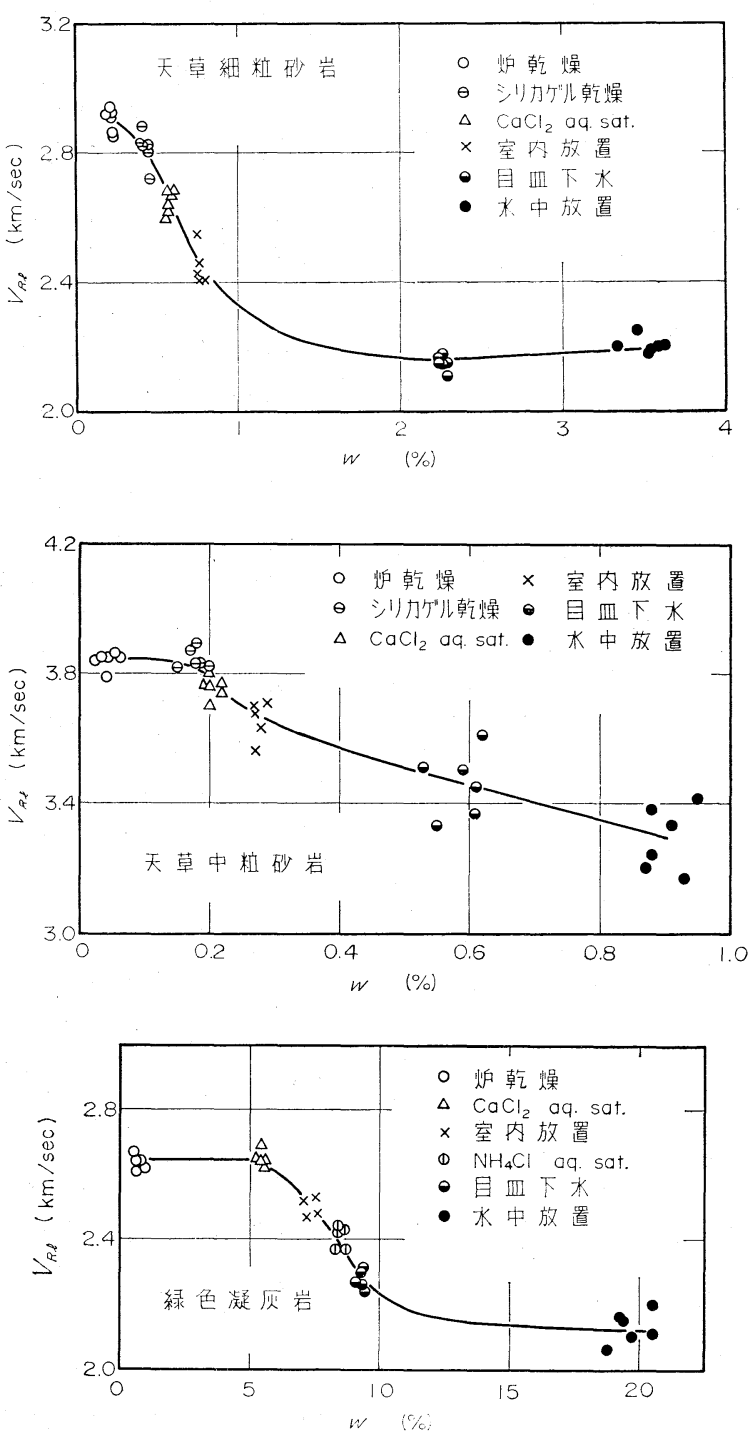

上より 第13・14・15図

含水比の変化にともなう縦振動伝播速度の変化

はずである。測定点が少ないので明確ではないが，含水 比一強度線図の変曲点に相当するものが含水比一速度線 図にも認められる。これからみて, 前述した多孔質岩石 の孔隙内の水が強度や伝播速度に及ぼす効果に関する説 明は妥当であろうと思われる。

\section{4. 結言}

岩石供試体の弾性波伝播速度や一軸圧縮強さが含水比 の変化とともにどのように変化するかといらことに関し て堆積岩試料で実験的に検討したが, 得られた結果を要 約すると以下のごとくである。

（1）一軸圧縮強さ $\sigma_{c}$ は含水比 $w の$ 変化とともに指数 関数的に増減し

$$
\sigma_{c}=a \mathrm{e}^{-b w}+c
$$

という関数で表わすことができた。また，含水比一強度 (半対数) 線図を描くと 2 本の直線が折れ曲がる含水比 
の点があることが認められた。

（2）超音波パルス法で縦波伝播速度を測定するとあ る含水比で伝播速度が最低になる。この含水比よりさら に含水比が大になると縦波伝播速度は増加する。また, そのある含水比より含水比が小になると縦波伝播速度は 増加する。

（3）共振法で縦振動伝播速度を測定すると超音波パ ルス法の結果とは異なり，飽和含水状態に近づいても伝 播速度は増加しないで, ほとんど変化しないかあるいは わずか減少する。

（4）圧縮強さ, 縦波伝播速度および縦振動伝播速度 ともに含水比の増減にともなつてある含水比付近で変曲 点を生するが，この含水比付近を境として，孔隙内に存 在する水が主として自由水として挙動するか毛管水とし て挙動するか区別できるように考えられる。

上に列記したようなことを考え合せると，種々の含水 状態の岩石供試体の弾性波伝播速度より非破壊的に岩石

の強度を推定しようとするには，超音波パルス法よりも 共振法によつて测定した伝播速度の方が，含水比との関 係において類似した関係があるのでより適しているとも 思われるが，共振周波数を測定するらえで供試体の長さ の制限や整形の簡単さなどから考えると，ある特定の養 生状態の供試体で測定するならば超音波パルス法の方が 簡単である。

参 考 文 献

1）堀部富男・小林良二・村上孝・奥村清彦：東北鲑山，第 12 巻第 1 号, p. 6 $\sim 11$ (1965)

2）田中芳則：応用地犋，第 9 巻第 2 号，p. 82 93 (1968)

3) 谷津栄寿: 第 1 回岩の力学国内シンポジムム詳演集, p. 145 154 (1964)

4) 南雲昭三郎: 地質調查所月報, 第 8 卷第 9 号, p. $27 \sim 56$ (1957)

5）林田精郎：応用地質，第 6 巻第 4 号, p. 189 198 (1965)

6) 井上正康・大見美智人 - 菊田毅 : 応用地質, 第 11 巻第 4 号, p. $6 \sim 12$ (1970)

7) 井上正康・大見美智人: 物理探鉣, 第 23 巻第 4 号, p. 1 9 (1970)

8）松尾新一郎・木暮敬二：土之基璴，第17巻第 7 号，P. 19 25（1969）

9）井上正康・大見美智人：日本釷業会昭和46年度春季大会講演要旨集

10）宫崎政三・高椅彦治 : 土木地質学, 共立出版, p. 112 (1970)

11) G. H. F. Gardner: J. A. S. A, Vol. 34, No. 1, p. 36 40 (1961)

\title{
Study on the Relationship of Water Content to Velocities of Elastic Waves and Compressive Strength of Sedimentary Rocks
}

\author{
by Masayasu INOUE, Michito ŌMI and Jun-ichi MORITA
}

Rock specimens curred at various curring circumstances were prepared for this experiment. Dilatational wave velocity measured by ultrasonic pulse method, longitudinal vibration velocity measured by resonance frequency method and uniaxial compressive strength of the rock specimens were investigated and described to water content of them.

Results obtained in this paper are summarized as follows:

(1) The uniazial compressive strength varies in the form of following exponential relation as a function of the water content of rocks

$$
\sigma_{c}=a \mathrm{e}^{-b w}+c
$$

Where, $\sigma_{c}$; uniaxial compressive strength $\left(\mathrm{kg} / \mathrm{cm}^{2}\right), w$; water content $(\%)$ and $a, b$ and $c$; constants.

(2) It was found that the rocks have a specific water content value which dilatational wave velocity becomes minimum. In the range of specific water content from this point to saturated state the dilatational wave velocity increases as the water content increases, and it increases again as the water content decreases in the range from the point to dry state.

(3) The longitudinal vibration velocity does not increase just as the dilatational wave velocity does. The velocity does not vary or tends to decrease slightly, as the water content approaches to saturation.

(4) At a certain specific water content, there is a point of inflection on this experimental curve relating of compressive strength, dilatational wave and longitudinal vibration velocity to water content of rocks. At the point of a certain specific water content, the action of the pore water is considered to divide into two stages, the one acts chiefly in free water the other acts chiefly in capillary water. 